\title{
Articles
}

\section{The Many Uses of Anti-Money Laundering Regulation-Over Time and into the Future}

\author{
By Maria Bergström*
}

\begin{abstract}
Given the fast development of the field of AML Regulation, this Article aims to answer the following questions: First, how is money laundering dealt with and regulated on the EU level? Second, to which legal concerns do the chosen regulatory strategy give rise? Accordingly, this Article provides an overview of the various regulatory strategies in the global and EU regional AML Regime while at the same time points out some of the most pressing legal concerns in AML Regulation. These include the blurred line between administrative and criminal law measures and the protection of individual rights and fundamental freedoms including data protection and privacy issues in administrative and criminal law contexts respectively. Although briefly mentioning the global and international context, the focus of this Article is the EU regulatory action, its outcome and critique, and possible future.
\end{abstract}

* Associate Professor in European Law, Faculty of Law, Uppsala University. 


\section{A. Introduction}

Modern regulatory activities often span from global initiatives and regional legislative processes to national implementation and application. The regulatory field of anti-money laundering (AML) regulation is no exception. AML regulation is a fascinating field that not only embraces various types of actors and interests, actions, and processes, but also faces challenges and shortcomings on a variety of levels and contexts. More specifically, within the European Union (EU), the applicable administrative and criminal law frameworks stem mainly from EU Regulation, which in turn transpose and closely follow complementary activities carried out in international fora, in particular those of the Financial Action Task Force (FATF), ${ }^{1}$ the United Nations, the Council of Europe, and also banking organizations. ${ }^{2}$

Whereas money laundering and terrorist financing are frequently carried out in an international context with regulation on different levels beyond the national level, the regulatory context is widened in other respects as well. The European Agenda on Security ${ }^{3}$ published in 2015 called for additional measures in the areas of terrorist financing and money laundering. The 2016 Action Plan to strengthen the fight against terrorist financing ${ }^{4}$ highlighted the need to counter money laundering by means of criminal law and the need to ensure that criminals who fund terrorism are deprived of their assets. After the entry into force of the Lisbon Treaty in 2009, money laundering is one of the so-called Euro-crimes with a specific criminal law legal basis in Article 83(1) of the Treaty on the Functioning of the European Union (TFEU). Additionally, the fourth AML Directive-soon to be amended by the fifth AML Directive-includes tax crime as a new predicate offence. ${ }^{5}$

\footnotetext{
${ }^{1}$ FATF is an inter-governmental body that was established in 1989 by the Ministers of its member jurisdictions FATF home page at http://www.fatf-gafi.org/about/ (last visited Mar. 6, 2018).

${ }^{2}$ See, e.g., Maria Bergström, EU Anti-Money Laundering Regulation: Multilevel Cooperation of Public and Private Actors, in Crime Within the Area of Freedom, SeCurity and Justice: A European Public Order (Christina Eckes \& Theodore Konstadinides eds., 2011) [hereinafter Bergström 2011].

${ }^{3}$ See European Commission, Communication from the Commission to the European Parliament, the Council, the European Economic and Social Committee and the Committee of the Regions, the European Agenda on Security, COM (2015) 185 final (Apr. 28, 2015).

${ }^{4}$ See Communication from the Commission to the European Parliament and the Council on an Action Plan for Strengthening the Fight Against Terrorist Financing, COM (2016) 50 final (Feb. 2, 2016).

${ }^{5}$ Directive 2015/849/EU of the European Parliament and of the Council of 20 May 2015 on the Prevention of the Use of the Financial System for the Purposes of Money Laundering or Terrorist Financing, Amending Regulation (EU) 648/2012 of the European Parliament and of the Council, and Repealing Directive 2005/60/EC of the European Parliament and of the Council and Commission Directive 2006/70/EC, 2015 O.J. (L 141) 73. [hereinafter Fourth AML Directive] (In the case of money laundering, a predicate offense may cover actions used to obtain the initial funds.).
} 
Given the fast development of the field of AML Regulation, this Article aims at answering the following questions: First, how is money laundering dealt with and regulated on the EU level? Second, to which legal concerns do the chosen regulatory strategy give rise? Accordingly, this Article provides an overview of the various regulatory strategies in the global and EU regional AML Regime while at the same time points out some of the most pressing legal concerns in AML Regulation. These include the blurred line between administrative and criminal law measures and the protection of individual rights and fundamental freedoms including data protection and privacy issues in administrative and criminal law contexts respectively. Although briefly mentioning the global and international context, the focus of this Article is EU regulatory action, its outcome and critique, and possible future. ${ }^{6}$

\section{B. The Broader Regulatory Framework-The EU Security Agenda and Transnational Crime Prevention}

In April 2015, the European Commission presented the European Agenda on Security for the period of 2015-2020. ${ }^{7}$ Highlighting that the primary goal of organized crime is profit and that international criminal networks use legal business structures to conceal the source of their profits, the European Agenda on Security called for a strengthening of the capacity of law enforcement to tackle the finance of organized crime. Besides the fight against organized crime and cybercrime, preventing terrorism and countering radicalization are identified as the most pressing challenges.

The European Agenda on Security will support Member States' cooperation in tackling these security threats. Key actions include effective measures to "follow the money" and cutting the financing of criminals, where cooperation between competent authorities will be strengthened, in particular the national Financial Intelligence Units (FIUs), which will be connected to Europol. In addition, Eurojust could offer more expertise and assistance to national authorities when conducting financial investigations. The idea is that cross-border cooperation between national FIUs and national Asset Recovery Offices (AROs) will help to

\footnotetext{
${ }^{6}$ This Article builds upon and develops from my previous publications. See generally Bergström 2011, supra note 2; Maria Bergström, The Place of Sanctions in the EU System for Combating the Financing of Terrorism, in EU SANCTIONS: LaW and Policy Issues Concerning Restrictive Measures (Lain Cameron ed., 2013); Maria Bergström, Money Laundering, in RESEARCH HANDBOOK ON EU CRIMINAL LAW (Valsamis Mitsilegas, Maria Bergström \& Theodore Konstadinides, eds., 2016) [hereinafter Bergström 2016]; Maria Bergström, The Global AML Regime and the EU AML Directives - Prevention and Control, in THE HANDBOOK OF CRIMINAL AND TERRORISM FINANCING LAW (Colin King, Clive Walker \& Jimmy Gurule eds., 2018) [hereinafter Bergström 2018a]; Maria Bergström, Legal Perspectives on Money Laundering, in Research HANdBook on Transnational Crime (Valsamis Mitsilegas \& Saskia Hufnagel eds., Edward Elgar, forthcoming in 2018) [hereinafter Bergström 2018b].

${ }^{7}$ The European Agenda on Security, supra note 3.
} 
combat money laundering and to access the illicit proceeds of crime. ${ }^{8}$ The powers of FIUs will thereby be reinforced to better track the financial dealings of organized crime networks and to enhance the powers of competent national authorities to freeze and confiscate illicit assets. The European Agenda on Security thus aims at "tackling the nexus between terrorism and organized crime, highlighting that organized crime feeds terrorism through channels like the supply of weapons, financing through drug smuggling, and the infiltration of financial markets." 9

The European Agenda on Security for 2015-2020 specifically called for additional measures in the area of terrorist financing and money laundering. Indeed the rules against money laundering and terrorist financing adopted in May 2015, such as the fourth AML Directive ${ }^{10}$ and the first AML Criminal Law Directive proposed in December 2016, ${ }^{11}$ are key actions. ${ }^{12}$ Besides legislation against money laundering, the EU further contributes to preventing the financing of terrorism through the network of EU FIUs and the EU-US Terrorist Finance Tracking Programme. ${ }^{13}$

In February 2016, the Commission presented an Action Plan to further step up the fight against the financing of terrorism. ${ }^{14}$ In brief, the plan has two main objectives. First, it aims to prevent the movement of funds and identify terrorist funding. In this respect, key actions include: Ensuring virtual currency exchange platforms are covered by the AML Directive; tackling terrorist financing through anonymous pre-paid instruments such as pre-paid cards; improving access to information and cooperation among EU FIUs; ensuring a high level of safeguards for financial flows from high risk third countries; and giving EU FIUs access to

${ }^{8} / d$.

${ }^{9}$ Proposal for a Directive of the European Parliament and of the Council on Countering Money Laundering by Criminal Law, COM (2016) 826 final (Dec. 21, 2016).

${ }^{10}$ See Fourth AML Directive, supra note 5; Regulation (EU) 2015/847 of the European Parliament and of the Council of 20 May 2015 on Information Accompanying Transfers of Funds and Repealing Regulation (EC) 1781/2006, 2015 O.J. (L 141) 1.

${ }^{11}$ See Proposal for a Directive of the European Parliament and of the Council on Countering Money Laundering by Criminal Law, COM (2016) 826 final (Dec.21, 2016) [hereinafter AML Criminal Law Directive].

${ }^{12}$ The European Agenda on Security, supra note 3; Press Release, European Commission, Commission Takes Steps to Strengthen EU Cooperation in the Fight Against Terrorism, Organised Crime and Cybercrime (Apr. 28, 2015), http://europa.eu/rapid/press-release_IP-15-4865_en.htm (last visited Apr. 8, 2017); see also European Parliament Resolution of 17 December 2014 on Renewing the EU Internal Security Strategy, 2014/2918(RSP), PARL. Doc. P8_TA(2014)0102, www.europarl.europa.eu/sides/getDoc.do?pubRef=-//EP//TEXT+TA+P8-TA-20140102+0+DOC+XML+V0//EN.

${ }^{13}$ See European Commission, Fact Sheet: European Agenda on Security: Questions and Answers, MEMO/15/4867 (28 Apr. 28, 2015), http://europa.eu/rapid/press-release_MEMO-15-4867_en.htm.

${ }^{14}$ See Action Plan for Strengthening the Fight against Terrorist Financing, supra note 4, at 2. 
centralized bank and payment account registers and central data retrieval systems. Secondly, the plan aims to disrupt sources of revenue for terrorist organizations. Key actions include: Tackling terrorist financing sources-such as the illicit trade in goods, cultural goods, and wildlife, and working with third countries to ensure a global response to tackling terrorist financing sources. ${ }^{15}$ Accordingly, the EU AML Regime is central also for the Action Plan for Strengthening the Fight Against Terrorist Financing. ${ }^{16}$

Whereas the European Agenda on Security called for additional measures in the area of terrorist financing and money laundering, the Commission's Action Plan ${ }^{17}$ highlighted the need to counter money laundering by means of criminal law and the need to ensure that criminals who fund terrorism are deprived of their assets. The next step is therefore to investigate how these regulatory challenges have been dealt with by the EU legislator.

\section{A Two-Tier European Union Power to Regulate}

After the entry into force of the Lisbon Treaty in 2009, TFEU has given particular attention to a number of cross-border crimes such as money laundering. Thus, money laundering is one of the so-called Euro-crimes with a specific criminal law legal basis in Article 83(1) TFEU. Despite the new criminal law competence to adopt EU criminal law measures directly based on Article 83(1) and the proposal for a first EU AML Criminal Law Directive, ${ }^{18}$ the current AML framework mainly consists of two legal instruments, both based on Article 114 TFEU on the internal market: The fourth AML Directive, ${ }^{19}$ soon to be amended by the recently adopted fifth AML Directive, ${ }^{20}$ and the Transfer of Funds Regulation. ${ }^{21}$

In order to avoid annulment by the Court of Justice of the European Union (CJEU), the predominant purpose of both instruments is ostensibly to improve the conditions for the establishment and functioning of the internal market, rather than to define criminal law

\footnotetext{
${ }^{15}$ See European Commission, Fact Sheet: Action plan to strengthen the Fight Against Terrorist Financing. European Agenda on Security (Dec. 2016), http://ec.europa.eu/newsroom/document.cfm?doc_id=40720.

${ }^{16}$ See generally Bergström 2018b, supra note 3 .

${ }^{17}$ See Action Plan for Strengthening the Fight Against Terrorist Financing, supra note 4.

${ }^{18}$ See AML Criminal Law Directive, supra note 11.

${ }^{19}$ See Fourth AML Directive, supra note 5.

${ }^{20}$ See Directive (EU) 2018/843 of the European Parliament and of the Council of 30 May 2018 Amending Directive (EU) 2015/849 on the Prevention of the Use of the Financial System for the Purposes of Money Laundering or Terrorist Financing, and Amending Directives 2009/138/EC and 2013/36/EU, 2018 O.J. (L 156) 43.

${ }^{21}$ See Regulation (EU) 2015/847, supra note 10.
} 
offenses and sanctions. Yet, their main aim is still the prevention of the use of the financial system for the purposes of money laundering and terrorist financing. ${ }^{22}$ This has indirectly been confirmed by the Court of Justice in Jyske Bank Gibraltar. ${ }^{23}$ In this case, the Court stated that, admittedly, the now repealed third AML Directive ${ }^{24}$ was founded on a dual legal basis, ${ }^{25}$ and it also sought to ensure the proper functioning of the internal market. The Court then went on to state that the Directive's main aim was the prevention of the use of the financial system for the purposes of money laundering and terrorist financing. This was apparent both from its title and the preamble, and from the fact that it was adopted, like its predecessor, ${ }^{26}$ in an international context in order to apply and make binding in the EU the recommendations of the FATF. In other words, both instruments now in force, update existing EU legal instruments on money laundering and the financing of terrorism and aim to implement and extend the newest FATF recommendations issued in February 2012, most recently updated in February 2018. ${ }^{27}$

Yet, despite all assumptions and suggestions that the current EU AML framework is mainly administrative in character, there is a floating and vague line between administrative law and criminal law and sanctions, not least since national laws and EU law are intertwined and interrelated.

First, because the fourth AML Directive provides for an EU-wide definition of money laundering, ${ }^{28}$ it might be argued that the current AML framework does establish harmonized rules when it comes to the definition of money laundering. EU rules stipulate what behavior is considered to constitute a criminal act, but does not state what type and level of sanctions are applicable for such acts. More specifically, the Directive clearly states that Member States shall ensure that money laundering and terrorist financing are prohibited, ${ }^{29}$ but it

\footnotetext{
${ }^{22}$ See also Bergström 2016, supra note 6.

${ }^{23}$ See Case C-212/11, Jyske Bank Gibraltar v. Administración del Estado, ECLI:EU:C:2013:270, para. 46, Judgement of 25 April 2013

${ }^{24}$ See Directive 2005/60/EC of the European Parliament and of the Council of 26 October 2005 on the Prevention of the Use of the Financial System for the Purpose of Money Laundering and Terrorist Financing, 2005 0.J. (L 309) 15 [hereinafter Third AML Directive].

${ }^{25}$ Treaty on the Functioning of the European Union, Oct. 26, 2012, 2012 O.J. (C 326), arts. 53(1) \& 114.

${ }^{26}$ Council Directive 91/308/EEC of 10 June 1991 on Prevention of the Use of the Financial System for the Purpose of Money Laundering, 1991 O.J. (L 166) 77 [hereinafter First AML Directive].

27 Financial Action Task Force, The FATF Recommendations, http://www.fatfgafi.org/publications/fatfrecommendations/documents/fatf-recommendations.htmI\#UPDATES.

${ }^{28}$ Fourth AML Directive, supra note 5, art. 1(3) (not changed by the fifth AML Directive).

${ }^{29}$ Supra note 5, art. 1(2) (not changed by the fifth AML Directive).
} 
cannot and may not require States to have certain criminal law provisions in place with certain specific minimum and maximum sanctions for breaches. ${ }^{30}$ In other words, the internal market measures may not establish minimum rules concerning the definition of criminal offences and sanctions within the scope of Article 83(1) TFEU. Under the present situation, the Member States should ensure that administrative sanctions and measures in accordance with the fourth AML Directive and criminal sanctions in accordance with national law are in place. If adopted, the AML criminal law directive will change this situation. ${ }^{31}$

In this respect, the Commission claims that "All Member States criminalize money laundering but there are significant differences in the respective definitions of what constitutes money laundering, on which are the predicate offences-i.e. the underlying criminal activity which generated the property laundered-as well as the level of sanctions." 32 The Commission further argues that the current legislative framework is neither comprehensive nor sufficiently coherent to be fully effective, and that "The differences in legal frameworks can be exploited by criminals and terrorists, who can choose to carry out their financial transactions where they perceive anti-money laundering measures to be weakest." 33

The definitions, scope, and sanctions of money laundering offences affect cross-border police and judicial cooperation among national authorities and the exchange of information. Practitioners have reported that differences in criminal law pose obstacles to effective police co-operation and cross-border investigation. ${ }^{34}$ According to the Commission, there are significant differences in the respective definitions of what constitutes money laundering, the predicate offences, and the level of sanctions. Such differences in the scope of predicate offences make it difficult for FIUs and law enforcement authorities in one Member State to coordinate with other EU jurisdictions to tackle cross-border money laundering. ${ }^{35}$

Second, to provide a specific example of the interrelationship between criminal and administrative law under the Directive, according to recital 59, Member States should ensure the imposition of administrative sanctions and measures in accordance with this

\footnotetext{
${ }^{30}$ See Ester Herlin-Karnell, Is Administrative Law Still Relevant? How the Battle of Sanctions has Shaped EU Criminal Law, in RESEARCH HANDBOOK ON EU CRIMINAL LAW, supra note 6.

${ }^{31}$ At the time of writing in May 2018, the proposal has not been adopted.

${ }^{32}$ AML Criminal Law Directive, supra note 9, at 1.

${ }^{33} / d$.

${ }^{34} / d$. at 2.

${ }^{35} / d$. at 1 . This section builds upon and develops from Bergström 2018b, supra note 2.
} 
Directive, and the imposition of criminal sanctions, in accordance with their national law, does not breach the principle of ne bis in idem. In other words, it is the responsibility of the Member States to ensure that the parallel systems of administrative and criminal law sanctions do not breach the principle of ne bis in idem. ${ }^{36}$

Third, the fourth AML Directive further emphasizes that sanctions or measures for breaches of national provisions transposing the Directive must be effective, proportionate, and dissuasive. ${ }^{37}$ As pointed out by Koen Lenaerts and José Gutiérrez-Fons, ${ }^{38}$ the CJEU in Aंkerberg Fransson recalled that, when EU legislation does not specifically provide any penalty for an infringement of EU law or refers for that purpose to national laws, regulations and administrative provisions, the Member States have the freedom to choose the applicable penalties, i.e., administrative, criminal or a combination of the two. ${ }^{39}$ Yet, the resulting penalties must comply with the Charter of Fundamental Rights of the European Union (EU Charter) and be effective, proportionate, and dissuasive. ${ }^{40}$ Any measure based on Article 83(1) TFEU, however, will leave no such freedom to the Member States.

\section{The Criminal Law Proposal}

On December 21, 2016, two days after the compromise proposal aiming at amending the fourth AML Directive was adopted by the Council, ${ }^{41}$ the Commission submitted a proposal for a Directive on countering money laundering by criminal law-AML Criminal Law

\footnotetext{
${ }^{36}$ See, e.g., ECJ, Case C-524/15, Luca Menci, ECLI:EU:C:2018:197, Judgement of 20 March 2018; Case C-537/16 Garlsson Real Estate v. Consob, ECLI:EU:C:2018:193, Judgement of 20 March 2018; Joined Cases C-596/16 and C-597/16, Enzo Di Puma v. Consob v. Antonio Zecca, ECLI:EU:C:2018:192, Judgement of 20 March 2018.

${ }^{37}$ Fourth AML Directive, supra note 5, art. 58(1) (not changed by the fifth AML Directive).

${ }^{38}$ See Koen Lenaerts \& Jose Gutiérrez-Fons, The European Court of Justice and Fundamental Rights in the Field of Criminal Law, in RESEARCH HANDBOOK ON EU CRIMINAL LAW.

${ }^{39}$ See Case C-617/10 Åklagaren v. Hans Åkerberg Fransson, ECLI:EU:C:2013:105, para. 34, Judgement of 26 February 2013.

${ }^{40}$ See id., para. 36.

${ }^{41}$ On December 21, 2016, the Commission submitted two legislative proposals: The proposal for the Criminal Law AML Directive, COM (2016) 826 final (AML Criminal Directive, supra note 9), and a proposal for a Regulation on the mutual recognition of freezing and confiscation orders.
} 
Directive. This was the first proposal based on Article 83(1) TFEU, ${ }^{42}$ which identifies money laundering as one of the so called "Euro-crimes" with a particular cross-border dimension.

The proposal aims to counter money laundering by means of criminal law and enables the European Parliament and the Council to establish the necessary minimum rules on the definition of money laundering by means of directives adopted in accordance with the ordinary legislative procedure. The proposal would complement different pieces of EU legislation that require Member States to criminalize some forms of money laundering. It will partially replace Council Framework Decision 2001/500/JHA as regards the Member States bound by this proposal. ${ }^{43}$ According to the Commission proposal, the existing instruments at the EU level-and in particular the above-mentioned Framework Decisionare limited in scope and do not ensure a comprehensive criminalization of money laundering offences. $^{44}$

The proposal further complements Directive 2014/42/EU that aims at creating a common set of minimum rules for the detection, tracing, and confiscation of proceeds of crime across the EU, and Council Framework Decision 2008/841/JHA, which criminalizes the participation in an organized criminal group and racketeering. ${ }^{45}$ In addition, it reinforces and complements the criminal law framework with regard to offences relating to terrorist groups, in particular the Directive on Combating Terrorism, ${ }^{46}$ which sets a "comprehensive definition of the crime of terrorist financing, covering not only terrorist offences, but also terrorist-related offences such as recruitment, training and propaganda." 47

As stated in the Explanatory Memorandum of the criminal law proposal, the rationale behind the proposal was that terrorists often resort to criminal proceeds to fund their activities and use money laundering schemes in that process. Thus, the underlying idea is that criminalization of money laundering would contribute to tackling terrorist financing. ${ }^{48}$

\footnotetext{
${ }^{42}$ AML Criminal Law Directive, supra note 11.

${ }^{43}$ Council Framework Decision 2001/500/JHA of 26 June 2001 on Money Laundering, the Identification, Tracing, Freezing, Seizing and Confiscation of Instrumentalities and the Proceeds of Crime, 2001 O.J. (L 182) 1.

${ }^{44}$ AML Criminal Law Directive, supra note 9.

${ }^{45}$ Id. at 5 .

${ }^{46}$ Directive (EU) 2017/541 of the European Parliament and of the Council of 15 March 2017 on Combating Terrorism and Replacing Council Framework Decision 2002/475/JHA and Amending Council Decision 2005/671/JHA, 2017 O.J. (L 88) 6.

${ }^{47}$ AML Criminal Law Directive, supra note 9, at 5.

${ }^{48} / d$.
} 
Hence, one of the key measures was to consider a possible proposal for a minimum Directive on the definition of the criminal offence of money laundering, ${ }^{49}$ applying it to terrorist offences and other serious criminal offences, and to approximate sanctions. In other words, the proposed AML Criminal Law Directive is embedded in the global fight against money laundering and terrorist financing. It implements international obligations in this area including the Warsaw Convention and Recommendation 3 of the FATF. FATF Recommendation 3 in turn calls on countries to criminalize money laundering on the basis of the Vienna Convention of 1988 and the Palermo Convention of $2000 .^{50}$

According to the Progress Report from the Presidency to the Council, work on the proposal is progressing well in the Working Party on Substantive Criminal Law (DROIPEN). ${ }^{51}$ Since January 2017, the Working Party has been preparing a compromise text of the proposal as a basis for reaching a general approach at the Council. On May 30, 2017, a compromise text was presented by DROIPEN, which would constitute the basis for future negotiations with the European Parliament in the context of the ordinary legislative procedure. ${ }^{52}$

The consolidated compromise text of the proposed Directive, as resulting from these discussions and confirmed at COREPER on May 24, 2017, seeks to reflect the compromises achieved on the basis of the positions expressed by delegations. ${ }^{53}$ On the one hand, if the latest proposal for an AML Criminal Law Directive is adopted, it would expand the current EU focus from prevention to the control of money laundering and terrorist financing. On the other hand, as suggested by the Commission, the proposal, if adopted, will also reinforce the measures in place aimed at detecting, disrupting, and preventing the abuse of the financial system for money laundering and terrorist financing purposes, notably the fourth AML Directive. This Directive, along with the Transfer of Funds Regulation, ${ }^{54}$ sets out rules which are designed to prevent the abuse of the financial system for money laundering and terrorist financing purposes. ${ }^{55}$

\footnotetext{
${ }^{49}$ Action Plan for Strengthening the Fight Against Terrorist Financing, supra note 4.

${ }^{50}$ United Nations Convention Against Transnational Organized Crime, Nov. 15, 2000, 2225 U.N.T.S. 209.

51 Interinstitutional Files: 2016/0414 (COD) 2016/0412 (COD), Progress Report from Presidency to Council, Combatting Financial Crime and Terrorism Financing (Mar. 20, 2017).

52 Interinstitutional File: 2016/0414 (COD), Progress Report from Presidency to Council, Concerning Proposal for a Directive of the European Parliament and of the Council on Countering Money Laundering by Criminal Law [First reading] General Approach (May 30, 2017).

${ }^{53} / d$.

${ }^{54}$ Regulation (EU)2015/847, supra note 10.

${ }^{55}$ See also Bergström 2018b, supra note 2; Bergström 2018a, supra note 2.
} 


\section{The EU Administrative Law Directives}

\section{Compensatory Measures and the Risk-based Approach}

The EU AML Directive from 1991-the first AML Directive-was the first stage in combating money laundering at the European level. ${ }^{56}$ The preamble of the first AML Directive stated that money laundering must be combated mainly by penal means and within the framework of international cooperation among judicial and law enforcement authorities. Yet, the directive recognized that a penal approach should not be the only way to combat money laundering "since the financial system can play a highly effective role." ${ }^{57}$ The preamble further stated that money laundering has an evident influence on the rise of organized crime in general and drug trafficking in particular. It continued on to say that there is increasing awareness that combating money laundering is one of the most effective means of opposing this form of criminal activity, which constitutes a particular threat to the Member States' societies.

The shift towards the risk-based approach and the extension to include the financing of terrorism ${ }^{58}$ as money laundering predicate offence were both introduced with the third AML Directive at the European level. ${ }^{59}$ Even today these remain two of the major changes within this regulatory field. This shift brought the regional EU rules in line with the global standard, revised and expanded FATF recommendations. ${ }^{60}$

First, each country should criminalize the financing of terrorism, terrorist acts, and terrorist organizations, and ensure that such offences are designated as money laundering predicate offences. ${ }^{61}$ FATF also agreed upon rules about freezing and confiscating terrorist assets, ${ }^{62}$ rules about reporting suspicious transactions related to terrorism, ${ }^{63}$ and rules concerning international co-operation, alternative remittance, wire transfers, and non-profit

\footnotetext{
${ }^{56}$ First AML Directive, supra note 26.

${ }^{57} / d .$, n.18.

${ }^{58}$ Third AML Directive, supra note 24, recital 8.

${ }^{59} / d$.

${ }^{60}$ FATF, FATF 40 Recommendations (Oct. 2004).

${ }^{61}$ Id., Special Recommendation II.

${ }^{62}$ Id., Special Recommendation III.

${ }^{63}$ Id., Special Recommendation IV.
} 
organizations. ${ }^{64}$ On 22 October 2004, a ninth special recommendation on cash couriers was developed with the objective of ensuring that terrorists and other criminals cannot finance their activities or launder the proceeds of their crimes through the physical cross-border transportation of currency and bearer negotiable instruments. ${ }^{65}$

Second, the "risk-based approach" 66 was given a prominent position in the third AML directive, as well as in the amended FATF recommendations upon which it builds. ${ }^{67}$ The starting point is that risks differ among countries, customers, and business areas over time. The operators themselves are the best analysts of where the risk areas are, or might arise, as they know best their businesses and their customers. The idea is that resources should be used where needs arise and the framework is supposed to be more flexible and adjustable to risk. Within a risk-based approach, businesses are expected to make risk assessments of their customers and divide them into low and high-risk categories. In order to enable operators to assess whether a situation involves a risk of money laundering and terrorist financing and to act accordingly, the directive introduced more detailed provisions. For this purpose, the directive specified a number of customer due diligence (CDD) measures that are more extensive and far-reaching for situations of higher risk, such as appropriate procedures to determine whether a person is a politically exposed person (PEP). The riskbased approach further emphasizes that the evaluation of who is high or low risk is to be a continuous process. As a result, the concept of "know your customer," as used in the financial sector, in practice became applicable to all covered by the directive. ${ }^{68}$

\footnotetext{
${ }^{64}$ Id., Special Recommendations V-VIII (Recommendation VI has been covered by Directive 2007/64/EC of the European Parliament and of the Council of 13 November 2007 on Payment Services (PSD) in the Internal Market, 2007 O.J. (L 319) 1, and Recommendation VII was addressed by Regulation (EC) 1781/2006 of the European Parliament and of the Council of 15 November 2006 on Information on the Payer Accompanying Transfers of Funds, 2006 O.J. (L 345) 1.).

${ }^{65}$ Id., Special Recommendation IX (being covered by Regulation (EC) 1889/2005 of the European Parliament and of the Council of 26 October 2005 on controls of cash entering or leaving the Community, 2005 O.J. (L 309) 9).

${ }^{66}$ See generally Michael Power, The Risk Management of EVerything (2004); Michael PoWer, ORganized UnCertainty (Oxford Univ. Press, 2007) (explaining that risk management is expanding in both range and scope across organizations in the public and the private sectors and has become something of a contemporary standard for dealing with uncertainty in an organized manner). For an integrated analysis of the concepts of risk and securitization, see generally Maria Bergström, Ulrika Mörth \& Karin Svedberg Helgesson, A New Role for For-Profit Actors? The Case of Anti-Money Laundering and Risk Management, 5 J. CoMmONs MKT. STUD. 1043 (2011) (showing between the concepts of risk and securitization, both emphasizing the structural threats and uncertainties in the case of AML); see also Valsamis Mitsilegas, Money Laundering Counter-Measures In the EUROPEAN UNION 3 (2003) (discussing "reconceptualizing security in the risk society").

${ }^{67}$ See generally Ester Herlin-Karnell, The EU's Anti Money Laundering Agenda: Built on Risks?, in CRIME WITHIN THE AREA OF FREEDOM, SECURITY AND JUSTICE, supra note 2 (a critical analysis of the risk-based approach).

${ }^{68}$ See generally Bergström 2018a, supra note 2.
} 


\section{Towards a More Targeted and Focused Risk-Based Approach}

The current AML framework consists of two legal instruments both based on Article 114 TFEU on the internal market: The fourth AML Directive ${ }^{69}$ and the Transfer of Funds Regulation. ${ }^{70}$ Both instruments update existing EU legal instruments on money laundering and the financing of terrorism and aim to implement and extend the newest recommendations issued in February 2012 by the FATF. ${ }^{71}$

The fourth AML Directive aims to prevent the Union's financial system from abuse for purposes of money laundering and terrorist financing. ${ }^{72}$ The risk-based approach ${ }^{73}$ has been further developed towards a more targeted and focused risk-based approach using evidence-based decision-making, as well as guidance by European supervisory authorities. ${ }^{74}$ In this respect, the new framework clarifies how AML supervisory powers apply in cross-border situations. These changes have the aim of updating the EU rules to implement the newest FATF recommendations, with their increased focus on the effectiveness of regimes to counter money laundering and terrorist financing, as well as addressing the shortcomings of the third AML Directive identified by the European Commission. ${ }^{75}$

\footnotetext{
${ }^{69}$ Fourth AML Directive, supra note 5.

${ }^{70}$ Regulation (EU) 2015/847, supra note 10.

${ }^{71}$ International Standards on Combating Money Laundering and the Financing of Terrorism and Proliferation: The FATF Recommendations (2012, most recently updated Feb. 2018), http://www.fatfgafi.org/publications/fatfrecommendations/documents/fatf-recommendations.html.

${ }^{72}$ Fourth AML Directive, supra note 5, art. 1(1).

${ }^{73}$ See, e.g., Herlin-Karnell, supra note 67; Bergström, supra note 2; Bergström, 2016, supra note 6, n. 27.
}

${ }^{74}$ Fourth AML Directive, supra note 5. Recital 23, for example, states that underpinning the risk-based approach is the need for member states and the Union to identify, understand, and mitigate the risks of money laundering and terrorist financing that they face. The importance of a supranational approach to risk identification has been recognized at the international level, and the European Supervisory Authority (European Banking Authority) (EBA), established by Regulation (EU) 1093/2010 of the European Parliament and of the Council, the European Supervisory Authority (European Insurance and Occupational Pensions Authority) (EIOPA), established by Regulation (EU) 1094/2010 of the European Parliament and of the Council, and the European Supervisory Authority (European Securities and Markets Authority) (ESMA), established by Regulation (EU) 1095/2010 of the European Parliament and of the Council, should be tasked with issuing an opinion, through their Joint Committee, on the risks affecting the Union's financial sector. Recital 24 of the Fourth AML Directive then states that national and Union data protection supervisory authorities should be involved only if the assessment of the risk of money laundering and terrorist financing has an impact on the privacy and data protection of individuals.

${ }^{75}$ See European Commission, Report on the Application of the Third Anti-Money Laundering Directive: Frequently Asked Questions, MEMO/12/246 (Apr. 11, 2012), http://europa.eu/rapid/press-release_MEMO-12246_en.htm?locale=en (last visited Mar. 15, 2018) (explaining the review of the third AML Directive undertaken by the Commission, with a view to addressing any identified shortcomings). 
According to the Council, the Directive's strengthened rules "reflect the need for the EU to adapt its legislation to take account of the development of technology and other means at the disposal of criminals." 76

In general, the Directive's scope is extended by reducing the cash payment threshold that triggers reporting obligations from EUR 15,000 to EUR 10,000, by including providers of gambling services within its scope, and by including tax crimes as new predicate offenses. The new framework reinforces the sanctioning powers of the competent authorities, ${ }^{77}$ and the Directive stipulates a maximum administrative pecuniary sanction of up to twice the amount of the benefit derived from the breach where such benefit can be determined, or up to EUR 1 million. ${ }^{78}$ In addition, the fourth AML Directive incorporates new provisions on data protection. Besides these general changes, a few specific issues are worth mentioning.

First, risk-assessments are required at several different levels. At the EU level the Commission is obliged-at least biennially-to assess the risks of money laundering and terrorist financing affecting the internal market and relating to cross-border activities. ${ }^{79}$ The Member States in turn, shall assess the risks affecting them, including any data protection concerns.$^{80}$ Member States shall also ensure that obliged entities make risk assessments relating to their customers, countries or geographic areas, products, services, transactions, or delivery channels, all proportionate to the nature and size of the obliged entities. ${ }^{81}$

Second, there are tougher rules on customer due diligence (CDD), which require that banks and other relevant entities have in place adequate controls and procedures so that they know their customers and understand the nature of their customers' businesses. To the benefit of those involved, these rules have been clarified. As under the previous Directives, relevant entities can take simplified measures where risks are demonstrated to be lower, ${ }^{82}$ but are required to take enhanced measures where the risks are greater, ${ }^{83}$ including specific

\footnotetext{
${ }^{76}$ Press Release, European Council, Money Laundering: Council Approves Strengthened Rules (Apr. 20, 2015), www.consilium.europa.eu/en/press/press-releases/2015/04/20-money-laundering-strengthened-rules.

${ }^{77}$ Els De Busser \& Cornelia Riehle, Money Laundering: Fourth Anti Money Laundering Directive Released, 1 EUCRIM 6 (2013).

${ }^{78}$ Fourth AML Directive, supra note 5, art. 59(2)(e) (not amended by the fifth AML Directive).

${ }^{79}$ Id., art. 6(1) (not amended by the fifth AML Directive).

${ }^{80} / d$., art. 7(1) (not amended by the fifth AML Directive).

${ }^{81}$ Id., art. 8(1) (not amended by the fifth AML Directive).

${ }^{82} / d$., art. 15-17 (not amended by the fifth AML Directive); Id., Annex II (slightly amended by the fifth AML Directive).

${ }^{83} / d$., art. 18-24, (will be partly amended by the fifth AML Directive, including the insertion of the new articles $18 a$ and 20a).
} 
provisions on politically exposed persons (PEPs) at domestic level, and PEPs working for international organizations. ${ }^{84}$ The new Directive, however, will prescribe minimum factors to be taken into account before applying simplified measures, and obliged entities need to prove why they have considered the risk to be low.

Third, in order to enhance transparency, specific provisions on the beneficial ownership of companies have been introduced. Information about beneficial ownership will be stored in a central register accessible to competent authorities, FIUs, entities required to take CDD measures, and other persons with a legitimate interest. ${ }^{85}$ Such access to information needs to be in accordance with data protection rules and may be subject to online registration and the payment of a fee, not exceeding the administrative costs of obtaining the information. ${ }^{86}$ This section will be replaced by the fifth AML Directive, and in the future, Member States may, under conditions to be determined in national law, provide for access to additional information enabling the identification of the beneficial owner. That additional information shall include at least the date of birth or contact details in accordance with data protection rules. According to recital 14, access to accurate and up-to-date information on the beneficial owner is a key factor in tracing criminals who might otherwise hide their identity behind a corporate structure. In addition, new rules on traceability of fund transfers have been introduced.

Fourth, with the introduction of the fourth AML Directive, there will be more cooperation between national authorities. Of central importance, the role of national FIUs is to receive, analyze the exchange, and disseminate reports raising suspicions of money laundering or terrorist financing to competent authorities in order to facilitate their cooperation. ${ }^{87}$ In this respect, the FIUs have been given strengthened powers to identify and follow suspicious transfers of money and facilitate exchange of information. ${ }^{88}$ They now have the access to financial, administrative, and law enforcement information and are empowered to take early action if requested from the law enforcement authorities. According to recital 58, Member States should in particular ensure that their FIUs exchange information freely,

${ }^{84} /$ d. art. 20-23 (with a new article 20a inserted by the fifth AML Directive).

${ }^{85} / d$., art. 30 (will be amended by the fifth AML Directive).

${ }^{86} / d$., art. 30(5) para. 2 (will be amended by the fifth AML Directive).

${ }^{87} / d$., art. 32(3) (not amended by the fifth AML Directive).

${ }^{88}$ See also Council Decision 2000/642/JHA of 17 October 2000 Concerning Arrangements for Cooperation Between FIUs of the Member States in Respect of Exchanging Information, 2000 O.J. (L 271) 4 (the Commission also plans to update); European Commission, Report on the Application of the Third Anti-Money Laundering Directive: Frequently Asked Questions, MEMO/12/246 (Apr. 11, 2012) http://europa.eu/rapid/press-release_MEMO-12246_en.htm?locale=en. 
spontaneously or upon request, with third-country FIUs, having regard to Union law and to the principles relating to information exchange developed by the Egmont Group of Financial Intelligence Units. ${ }^{89}$

Despite the internal market legal basis, the wider regulatory framework can therefore be said to have changed from a predominantly single market context via criminal law concerns to the fight against organized crime, terrorist financing, and an internal security context based on the risk-based approach. The main focus of the global and regional EU measures based on the risk-based approach is, however, still set on preventive measures, whereas AML control is still a matter for national jurisdictions and the developing framework of international cooperation among judicial and law enforcement authorities. It remains to be seen if the proposal for an AML Criminal Law Directive will be adopted that would expand the current EU focus from prevention to control of money laundering and terrorist financing. Meanwhile, Member States are obliged to implement the fourth AML Directive, ${ }^{90}$ to which changes have already been adopted by the text of the fifth AML Directive signed on May 30, 2018. It will enter into force twenty days after its publication in the Official Journal (Article $5)$, and the Member States need to implement its provision eighteen months thereafter (Article 4). ${ }^{91}$

\section{Implementing the Action Plan for Strengthening the Fight Against Terrorist Financing}

About two years earlier, on July 5, 2016, the European Commission adopted the proposal to amend the fourth AML Directive and Directive 2009/101. The latter established the European Central Platform interconnecting Member States' central registers holding beneficial ownership information. ${ }^{92}$ The idea behind the amendments was to reinforce the preventive framework against money laundering, ${ }^{93}$ in particular by addressing emerging

\footnotetext{
${ }^{89}$ Egmont Group of Financial Intelligence Units Charter (July 2013) https://egmontgroup.org/en/documentlibrary/8.

${ }^{90}$ Fourth AML Directive, supra note 5, art. 66-67 (Article 6 will be amended by the fifth AML Directive.).

${ }^{91}$ See also Bergström 2018b, supra note 2; Bergström 2018a, supra note 2.

${ }^{92}$ Directive 2009/101/EC of the European Parliament and of the Council of 16 September 2009 on Coordination of Safeguards Which, for the Protection of the Interests of Members and Third Parties, are Required by Member States of Companies Within the Meaning of the Second Paragraph of Article 48 of the Treaty, with a View to Making Such Safeguards Equivalent 2009 O.J. (L 258) 11.

${ }^{93}$ The Proposal for a Directive of the European Parliament and of the Council Amending Directive (EU) 2015/849 on the Prevention of the use of the Financial System for the Purposes of Money Laundering or Terrorist Financing and Amending Directive 2009/101/EC, COM (2016) 450 final (July 5, 2016) (for the procedure, see http://eurlex.europa.eu/procedure/EN/2016_208).
} 
risks and increasing the capacity of competent authorities to access and exchange information. ${ }^{94}$

These amendments aim at ensuring a high level of safeguards for financial flows from high-risk third countries, enhancing the access of FIUs to information, including centralized bank account registers, and tackling terrorist financing risks linked to virtual currencies and pre-paid cards. In this respect, this recently adopted fifth AML Directive takes a stricter approach to the problem of effectively countering money laundering and terrorist financing and focuses on new channels and modalities of transferring illegal funds to the legal economy, such as virtual currencies and money exchange platforms.

The proposal was a coordinated action with the G20 and the OECD, aiming at tackling tax evasion by both legal and natural persons in order to establish a fairer and more effective tax system. In this respect, it formed part of a wider EU effort to improve tax transparency and tackle tax abuse. ${ }^{95}$ About five months after the Commission proposal, on December 19, 2016, the Council adopted a compromise text on the proposal aiming at amending the AML Directive, Directives 2009/138/EC (Solvency II), ${ }^{96}$ and 2013/36/EU, but not Directive 2009/101, focusing mainly on AML and terrorist financing. ${ }^{97}$ Although the purpose of fighting tax evasion is no longer explicitly mentioned, tools that were designed to achieve that purpose remain, although somewhat modified. ${ }^{98}$ Set in a broader picture, this initiative was the first proposal to enforce the Action Plan for Strengthening the Fight Against Terrorist Financing, ${ }^{99}$ which was adopted by the Commission on February 2, 2016 to better counter

\footnotetext{
${ }^{94}$ See generally Bergström 2018b, supra note 2.

95 Press Release, European Commission, Fair Taxation: The Commission Sets Out Next Steps to Increase Tax Transparency and Tackle Tax Abuse (July 5, 2016), http://europa.eu/rapid/press-release_IP-16-2354_en.htm.

${ }^{96}$ Directive 2009/138/EC of the European Parliament and of the Council of 25 November 2009 on the Taking-up and Pursuit of the Business of Insurance and Reinsurance (Solvency II) (recast), 2009 O.J. (L 335) 1. Solvency II is the new, risk-based supervisory framework for the insurance sector that entered into effect on 1 January 2016.

${ }^{97}$ Proposal for a Directive of the European Parliament and of the Council Amending Directive (EU) 2015/849 on the Prevention of the Use of the Financial System for the Purposes of Money Laundering or Terrorist Financing and Amending Directive 2009/101/EC, COM (2016) 450 final (Dec. 19, 2016), https://eur-lex.europa.eu/legalcontent/EN/TXT/PDF/?uri=CONSIL:ST_15605_2016_INIT\&from=EN.

${ }^{98}$ Council of the European Union, Presidency Compromise Text (Dec. 13, 2016), http://eur-lex.europa.eu/legalcontent/EN/TXT/PDF/?uri=CONSIL:ST_15468_2016_INIT\&from=EN (last visited Apr. 8, 2017). For the procedure, see http://eur-lex.europa.eu/legal-content/EN/HIS/?uri=CELEX:52016PC0450\&qid=1491076566465.
}

${ }^{99}$ Action Plan for Strengthening the Fight Against Terrorist Financing, supra note 4. 
the financing of terrorism, and to ensure increased transparency of financial transactions following the so-called "Panama Papers" revelations. ${ }^{100}$

Nevertheless, the proposed amendments have been criticized by the Data Protection Agency for introducing other policy purposes than countering money laundering and terrorist financing that do not seem clearly identified: Processing personal data collected for one purpose for another, completely unrelated purpose. This infringes on the data protection principle of purpose limitation and threatens the implementation of the principle of proportionality. The amendments, in particular, raise questions as to why certain forms of invasive personal data processing, acceptable in relation to AML and the fight against terrorism, are necessary out of those contexts and whether these invasive data processing are proportionate. ${ }^{101}$

The Data Protection Agency also criticizes the proposed amendments due to the lack of proportionality, in particular concerning the broadened access to beneficial ownership information by both competent authorities and the public as a policy tool to facilitate and optimize enforcement of tax obligations. The Data Protection Agency sees, "in the way such solution is implemented, a lack of proportionality, with significant and unnecessary risks for the individual rights to privacy and data protection." ${ }^{102}$

Eventually, on May 14, 2018, after almost two years of negotiations and counterproposals, the European Parliament and the Council adopted the fifth AML Directive. It was signed on May 30, 2018 and will enter into force twenty days after its publication. Member States will then have up to eighteen months to transpose the new provisions into their national legislation. ${ }^{103}$

\section{Conclusions}

\footnotetext{
${ }^{100}$ Communication from the Commission to the European Parliament and the Council: Communication on Further Measures to Enhance Transparency and the Fight against Tax Evasion and Avoidance, COM (2016) 451 final; see also European Commission, Commission Strengthens Transparency Rules to Tackle Terrorism Financing, Tax Avoidance and Money Laundering (July 5, 2016) http://europa.eu/rapid/press-release_IP-16-2380_en.htm.

${ }^{101}$ European Data Protection Supervisor, Summary of the Opinion of the European Data Protection Supervisor on a Commission Proposal Amending Directive (EU) 2015/849 and Directive 2009/101/EC Access to Beneficial Ownership Information and Data Protection Implications, 2017 O.J. (C 85) 3.

$102 / d$.

${ }^{103}$ Directive of the European Parliament and of the Council Amending Directive (EU) 2015/849 on the Prevention of the Use of the Financial System for the Purposes of Money Laundering or Terrorist Financing, and Amending Directives 2009/138/EC and 2013/36/EU (May 30, 2018), https://eur-lex.europa.eu/legalcontent/EN/TXT/?uri=consil:PE_72_2017_REV_1.
} 
Despite all assumptions and suggestions that the current EU AML framework is mainly administrative in character, there is not a clear line between administrative and criminal law and sanctions, not least since national laws and EU law are intertwined and interrelated. This may have detrimental effects concerning procedural safeguards and fundamental rights protection-for example if sanctions are in fact criminal rather than administrative in character, or if the different solutions chosen in different Member States, lead to variations in fundamental rights protection throughout the European Union.

So far, it is mainly the responsibility of the Member States to ensure that the parallel systems of administrative and criminal law sanctions do not breach fundamental rights including the principle of ne bis in idem, the rules on privacy and data protection, and the principle of proportionality. EU Law measures may, however, by themselves infringe fundamental rights. Processing personal data collected for one purpose for another, completely unrelated purpose infringes on the data protection principle of purpose limitation and threatens the implementation of the principle of proportionality. The Data Protection Supervisor-in particular concerning the proposed amendments to the fourth AML Directive-raised questions as to why certain forms of invasive personal data processing, acceptable in relation to AML and the fight against terrorism, are necessary out of these contexts and whether they are proportionate. Such issues need to be evaluated against national human rights catalogues, the European Convention of Human Rights, and the EU Charter of Fundamental Rights. This is even more important when dealing with criminal, rather than purely administrative, law provisions and sanctions, which might necessitate further legal analysis. 